\title{
Pertumbuhan Tanaman Serai Wangi (Cymbopogon nardus L) Pada Beberapa Dosis Kompos Kulit Kopi
}

\author{
${ }^{1}$ Rosliana Manurung, ${ }^{* 2}$ Yulistiati Nengsih, dan ${ }^{2}$ Ridawati Marpaung \\ ${ }^{1}$ Alumni Program Studi Agroteknologi, Fakultas Pertanian Universitas Batanghari \\ ${ }^{2}$ Program Studi Agroteknologi, Fakultas Pertanian Universitas Batanghari \\ Jl. Slamet Riyadi-Broni, Jambi. 36122 Telp +62074160103 \\ *2e mail korespondensi : nyulistiati@yahoo.com
}

\begin{abstract}
The purpose of this study was to determine the effect of giving coffee husk compost on the growth of citronella (Cymbopogon nardus L.) plants. This research was conducted in Kuala Tungkal, Tungkal Ilir District, West Tanjung Jabung Regency, Jambi Province, from December 2020 to March 2021. Analysis of compost nutrients was carried out at the Laboratory of the Jambi Agricultural Technology Research Center and measurements of root wet weight, shoot dry weight and root dry weight were carried out at the Basic Laboratory of Batanghari University Jambi. This research was conducted using a completly randomized design (CRD) and treatment design for coffee husk compost which consisted of 4 levels of treatment, namely $\mathrm{k} 0: 3 \mathrm{~kg}$ of soil media without treatment (control), $\mathrm{kl}: 15 \mathrm{~g}$ of coffee husk compost $+2,985 \mathrm{~g}$ of soil media, $\mathrm{k} 2: 22.5 \mathrm{~g}$ coffee husk compost $+2.977 .5 \mathrm{~g}$ soil media, and $\mathrm{k} 3: 30 \mathrm{~g}$ coffee husk compost $+2.970 \mathrm{~g}$ soil media. Parameters observed were number of tillers, number of leaves, fresh weight of roots, dry weight of shoot, dry weight of roots, shoot-root ratio, soil pH, nutrients content, and microclimate. Observational data were analyzed with anlysis of variance and treatment differences were tested with the DNMRT test with 95\% confidance. The results of the analysis showed that the application of coffee husk compost had a significant effect on the parameters of root wet weight, shoot dry weight and pH of the growing media but had no significant effect on the parameters of the number of tillers, number of leaves, root dry weight and root crown ratio.
\end{abstract}

Keywords : Coffe husk compost and citronella

\begin{abstract}
Abstrak. Tujuan penelitian ini adalah untuk mengetahui pengaruh pemberian kompos kulit kopi terhadap pertumbuhan tanaman serai wangi (Cymbopogon nardus L.). Penelitian ini dilaksanakan di Kuala Tungkal, Kecamatan Tungkal Ilir, Kabupaten Tanjung Jabung Barat, Provinsi Jambi, mulai bulan Desember 2020 hingga Maret 2021. Analisis unsur hara kompos dilakukan di Laboratorium Balai Pengkajian Teknologi Pertanian Jambi dan analisis tumbuh tanaman dilakukan di Laboratorium Dasar Universitas Batanghari Jambi. Penelitian ini dilakukan dengan menggunakan rancangan acak lengkap (RAL) dan rancangan perlakuan dosis kompos kulit kopi yang terdiri dari 4 taraf perlakuan yaitu $\mathrm{k}_{0}: 3 \mathrm{~kg}$ media tanah tanpa perlakuan (kontrol), $\mathrm{k}_{1}$ : $15 \mathrm{~g}$ kompos kulit kopi $+2.985 \mathrm{~g}$ media tanah, $\mathrm{k}_{2}: 22,5 \mathrm{~g}$ kompos kulit kopi $+2.977,5 \mathrm{~g}$ media tanah, dan $\mathrm{k}_{3}: 30 \mathrm{~g}$ kompos kulit kopi $+2.970 \mathrm{~g}$ media tanah. Parameter yang diamati adalah jumlah anakan, jumlah helai daun, bobot basah akar, bobot kering tajuk, bobot kering akar, nisbah tajuk akar, $\mathrm{pH}$ tanah, unsur hara, dan iklim mikro. Data hasil pengamatan dianalisis dengan sidik ragam dan pengujian perbedaan perlakuan dengan uji DNMRT ketelitian 95\%. Hasil analisis menunjukkan bahwa Pemberian kompos kulit kopi berpengaruh nyata terhadap parameter bobot basah akar, bobot kering tajuk dan $\mathrm{pH}$ media tanam tetapi berpengaruh tidak nyata terhadap parameter jumlah anakan, jumlah helai daun, bobot kering akar dan nisbah tajuk akar.
\end{abstract}

Kata kunci : Kompos kulit kopi dan serai wangi

\section{PENDAHULUAN}

Serai wangi (Cymbopogon nardus.L) adalah salah satu komoditi atsiri yang sangat prospektif. Permintaan minyak serai wangi cukup tinggi dan harganya stabil serta cenderung meningkat. Serai wangi saat ini banyak dikembangkan karena mempunyai syarat tumbuh yang relatif mudah, sehingga mudah dibudidayakan untuk pengembangan dalam skala luas pada berbagai jenis tanah (Setiawan, Gusmaini dan Hera, 2018). Tanaman ini juga dapat hidup pada kondisi ekstrim seperti tanah yang miskin hara, tanah basa, lereng terjal, dan hutan yang terdegradasi (Sopacua, 2016). Pertumbuhan serai wangi dapat dipengaruhi oleh kesuburan tanah. Tanah yang subur adalah tanah yang mengandung unsur hara, air dan bahan komponen lainnya. Menurut Rusli et al., (1990) untuk menjaga kesuburan tanah dan kestabilan produksi, tanaman serai wangi perlu dipupuk. Pupuk berpengaruh pada produksi daun dan banyaknya minyak atsiri yang dihasilkan per hektar.

Permasalahan dalam budidaya serai wangi yaitu petani masih menggunakan pupuk anorganik atau pupuk kimia, hanya sebagian kecil yang menggunakan pupuk organik. Penggunaan pupuk anorganik atau pupuk kimia secara terus menerus bila tidak dibarengi dengan penambahan bahan organic menyebabkan lahan pertanian mengalami degradasi kesuburan karena kehilangan bahan organik dan unsur hara yang pada akhirnya dapat menurunkan kualitas tanah dan produksi tanaman (Efendi, Sufardi dan Muyassir, 2014). Oleh karena itu, hal yang perlu dilakukan dalam memperbaiki kesuburan tanah adalah dengan melakukan penambahan bahan organik. Pupuk organik merupakan pupuk yang berasal dari bahan-bahan organik yang dapat diurai (dirombak) oleh mikroba, juga dapat menyediakan unsur hara yang dibutuhkan pada tanaman. Pupuk organik sangat berperan penting sebagai penyangga sifat fisik, kimia dan biologi tanah serta meningkatkan produktivitas tanah. Menurut Marsono dan Paulus 
(2011) beberapa kelebihan pupuk organik antara lain mengubah struktur tanah menjadi baik sehingga pertumbuhan juga semakin baik.

Kompos adalah bahan-bahan organik yang telah mengalami proses pelapukan karena adanya interaksi antara mikroorganisme (bakteri pembusuk) yang ada di dalamnya (Murbandono, 2008). Kompos memiliki fungsi untuk memperbaiki struktur tanah dan meningkatkan bahan organik tanah. Dari berbagai jenis pupuk organik yang beredar, jenis pupuk organik yang digunakan adalah kompos limbah kulit kopi. Limbah kulit kopi termasuk kedalam limbah organik padat yang dihasilkan dari perkebunan kopi ataupun dari pabrik pengolahan kopi menjadi biji kopi. Limbah kulit kopi mengandung bahan organik dan unsur hara yang potensial untuk digunakan sebagai media tanam (Ditjenbun, 2006). Unsur hara pada kompos limbah kulit kopi mampu meningkatkan kesuburan pada tanaman serta meningkatkan kesuburan tanah. Selain itu kompos limbah kulit kopi memiliki kelebihan diantaranya dapat memperbaiki struktur tanah, merangsang pertumbuhan akar, batang dan daun (Melisa, 2018). Hasil penelitian Ramli, Dwi dan Mulyadi (2013) menujukkan bahwa kandungan kompos kulit buah kopi yaitu kadar C-organik $10.80 \%$, kadar nitrogen $4,73 \%$, fosfor $0,21 \%$ dan kalium $2,89 \%$.

Menurut Valentiah, Listyarini dan Prijono (2015), aplikasi kompos limbah kulit kopi dapat meningkatkan bahan organik serta kandungan hara tanah.Hasil penelitian Hutapea, Armaini dan Isnaini (2018) menunjukkan bahwa pemberian kompos kulit kopi dosis 15 ton/ha memberikan respon yang baik terhadap pertambahan panjang batang, pertambahan jumlah anakan daun, berat segar bibit dan berat kering bibit tanaman karet. Hasil penelitian lain yang dilakukan Tumangger, Hapsoh dan Sukemi (2017) menyatakan bahwa pemberian kompos kulit kopi dosis 75 $\mathrm{g} / \operatorname{tanaman}(15 \mathrm{ton} / \mathrm{ha})$ memberikan peningkatan terhadap parameter pertambahan tinggi bibit sebesar 1,09\% dan berat kering tanaman bibit kelapa sawit.

\section{METODE PENELITIAN}

Penelitian ini dilaksanakan di Kuala Tungkal Kecamatan Tungkal Ilir, Kabupaten Tanjung Jabung Barat, Provinsi Jambi dengan ketinggian \pm 25 meter diatas permukaan laut. Penelitian dilaksanakan pada bulan Desember 2020 sampai Maret 2021. Analisis unsur hara kompos dilakukan di Laboratorium Balai Pengkajian Teknologi Pertanian Jambi dan pengukuran bobot basah akar, bobot kering tajuk dan bobot kering akar dilakukan di laboratorium dasar Universitas Batanghari Jambi.

Bahan yang digunakan dalam penelitian adalah bibit tanaman serai wangi varietas Sitrona 1 Agribun berumur \pm 7 bulan yang diperoleh dari Balai Penelitian Rempah dan Obat (Balitro) Bogor, kompos kulit kopi, pupuk NPK, media tanah Ultisol $3 \mathrm{~kg}$, air dan polybag berukuran $15 \mathrm{~cm}$ x $35 \mathrm{~cm}$.

Alat yang digunakan dalam penelitian adalah parang, cangkul, pisau, ember, ayakan, gembor, meteran, timbangan analitik, oven, $\mathrm{pH}$ meter, thermohygrometer, alat tulis dan alat pendukung lainnya.

Penelitian dilakukan dengan menggunakan rancangan acak lengkap (RAL) dan rancangan perlakuan dosis kompos kulit kopi $(\mathrm{k})$ yang terdiri dari 4 (empat) taraf perlakuan yaitu :k0 : $3 \mathrm{~kg}$ media tanah tanpa perlakuan (kontrol), k1 : 15 g kompos kulit kopi +2.985 g media tanah, k2 : 22,5 g kompos kulit kopi + 2.977,5 g media tanah, k3 : 30 g kompos kulit kopi +2.970 g media tanah. dengan 3 (tiga) kali ulangan sehingga terdapat 12 unit percobaan. Setiap unit percobaan terdiri dari 6 (enam) tanaman sehingga total tanaman keseluruhan adalah $4 \times 3 \times 6=72$ tanaman.

Areal tempat penelitian dibersihkan terlebih dahulu dari rumput-rumput serta sisa-sisa akar tanaman. Tempat penelitian yang tidak jauh dari sumber air. Bibit yang digunakan adalah bibit serai wangi varietas Sitrona 1 Agribun yang diperoleh dari Balai Penelitian Rempah dan Obat (BALITRO) Bogor. Setelah bibit serai wangi sampai dilokasi kondisi bibit diikat dan dikemas kedalam kardus tebal, kemudian kemudian bibit tersebut dimasukkan ke dalam wadah atau ember yang berisi air lalu bibit disimpan di tempat yang lembab. Bibit serai wangi yang dipesan dari BALITRO Bogor tidak memiliki daun dan akarnya sudah dipotong/dikurangi, dengan kriteria bibit yang sehat, berumur \pm 7 bulan, memiliki tinggi yang seragam sekitar $36 \mathrm{~cm}$, dan jumlah anakan 3 .

Media tanam menggunakan tanah ultisol, tanah yang diambil adalah tanah lapisan atas, setelah itu tanah dibersihkan dari rumput atau gulma. Tanah yang sudah dibersihkan kemudian dikering anginkan lalu diayak. Setelah diayak tanah ultisol dan pupuk kompos dicampur sesuai dengan perlakuan, kemudian media tanam diisi ke dalam polybag yang berukuran $15 \times 35 \mathrm{~cm}$ dengan berat media tanam $3 \mathrm{~kg}$. Kompos yang sudah dapat digunakan dicirikan sebagai berikut kompos berwarna hitam, tidak panas dan tidak berbau. Media tanam yang sudah tercampur diinkubasi selama 14 hari atau 2 minggu sebelum penanaman. Tujuan diinkubasi agar terjadi dekomposisi bahan organik berjalan dengan baik.

Pemberian pupuk dasar dilakukan diawal tanam pada saat menanam bibit serai wangi. Pupuk yang digunakan yaitu pupuk NPK dengan dosis setiap perlakuan yaitu $5 \mathrm{~g} /$ polybag (dosis sesuai anjuran).

Penanaman bibit serai wangi dilakukan dengan cara memilih bibit yang sehat, tidak memiliki daun dan akarnya sudah dipotong/dikurangi, berumur \pm 7 bulan, berukuran seragam dengan tinggi $36 \mathrm{~cm}$, jumlah anakan 3 . Kemudian bibit serai wangi ditanam ke dalam media tanam pada polybag yang telah disiapkan. 
Pemeliharaan yang dilakukan pada tanaman meliputi penyiraman, penyiangan gulma. Penyiraman tanaman dilakukan sekali dalam dua hari dengan memperkirakan kapasitas lapang sampai tanah benar-benar basah. Apabila hujan turun, tidak dilakukan penyiraman. Penyiangan terhadap gulma dilakukan dengan membuang rumput-rumput di sekitar tanaman di polybag secara manual. Pengendalian terhadap hama kutu putih dilakukan dengan penyemprotan larutan bawang putih sedangkan pengendalian terhadap penyakit jamur Fusarium dilakukan dengan penyemprotan Trichoderma.

Peubah yang diamati yang diamati dalam penelitian ini adalah:

1. Jumlah Anakan. Jumlah anakan adalah anakan yang muncul pada permukaan tanah. Pengamatan ini dilakukan diakhir penelitian yaitu 12 MST (minggu setelah tanam).

2. Jumlah Helai Daun. Pengamatan jumlah helai daun dilakukan diakhir penelitian (12 MST). Daun serai wangi yang dapat dihitung adalah seluruh daun yang telah membuka sempurna.

3. Bobot Basah Akar (g). Pengukuran bobot basah akar dilakukan diakhir penelitian (12 MST), dengan menggunakan timbangan analitik. Bagian akar dari bulu-bulu akar dibersihkan dari tanah yang menempel kemudian dibilas dengan air yang mengalir, selanjutnya dikering anginkan, lalu ditimbang.

4. Bobot Kering Tajuk (g). Pengukuran bobot kering tajuk dilakukan diakhir penelitian (12 MST), dengan cara mengeringkan tajuk tanaman mulai dari leher akar di permukaan tanah dalam oven dengan suhu $100^{\circ} \mathrm{C}$ selama $2 \times 24$ jam.

5. Bobot Kering Akar (g). Pengukuran bobot kering akar dilakukan diakhir penelitian (12 MST), dengan cara mengeringkan bagian akar dari bulu-bulu akar yang telah dikering anginkan di dalam oven pada suhu $100^{\circ} \mathrm{C}$ selama $2 \times 24$ jam.

6. Nisbah Tajuk Akar. Pengamatan ini dilakukan pada akhir penelitian (12 MST), dengan cara perhitungan dengan menggunakan rumus sebagai berikut $: N T A=\frac{B K T}{B K A}$. Keterangan :NTA: Nisbah Tajuk Akar, BKT: Bobot Kering Tajuk, BKA: Bobot Kering Akar

7. Pengukuran $\mathrm{pH}$ Tanah. Pengukuran $\mathrm{pH}$ media tanam dilakukan diawal dan diakhir penelitian dengan menggunakan alat ukur $\mathrm{pH}$ meter. Pengukuran $\mathrm{pH}$ media tanam dilakukan dengan cara menacapkan ujung alat $\mathrm{pH}$ meter ke dalam media tanam, kemudian tunggu beberapa saat sampai angka $\mathrm{pH}$ meter stabil di layar digital.

8. Analisis unsur hara dan $\mathrm{pH}$ kompos kulit kopi. Analisis kandungan kompos limbah kopi dilakukan di Laboratorium Balai Pengkajian Teknologi Pertanian Jambi, komponen yang dianalisis adalah unsur hara N, P, K, $\mathrm{C} / \mathrm{N}$ rasio dan $\mathrm{pH}$.

9. Data tambahan. Pengukuran data tambahan meliputi pengukuran suhu dan kelembaban dengan menggunakan alat thermohygrometer serta data tanaman yang terserang penyakit.

Untuk mengetahui pengaruh perlakuan yang dicobakan, maka data yang diperoleh dari hasil pengamatan dianalisis secara statistik dengan menggunakan analisis ragam dan jika berpengaruh nyata dilanjutkan dengan uji lanjut DNMRT pada taraf $\alpha 5 \%$.

\section{HASIL DAN PEMBAHASAN}

Hasil penelitian pemberian kompos kulit kopi menunjukkan perbedaan nyata pada parameter bobot basah akar, bobot kering tajuk dan $\mathrm{pH}$ media tanam tetapi berpengaruh tidak nyata pada jumlah anakan, jumlah helai daun, bobot kering akar dan nisbah tajuk akar.

\section{Jumlah anakan, jumlah helai daun, bobot kering akar dan nisbah tajuk akar}

Hasil analisis ragam menunjukkan pemberian kompos kulit kopi berpengaruh tidak nyata terhadap jumlah anakan, jumlah helai daun, bobot kering akar dan nisbah tajuk akar tanaman serai wangi pada akhir penelitian (12 MST). Hasil uji lanjut DNMRT taraf 5\% terhadap semua parameter dapat dilihat padaTabel 1.

Tabel 1. Rata-rata jumlah anakan, jumlah helai daun, bobot kering akar dan nisbah tajuk akar tanaman serai wangi pada berbagai dosis pemberian kompos kulit kopi pada umur 12 MST.

\begin{tabular}{lcccc}
\hline $\begin{array}{c}\text { Perlakuan } \\
\text { (Kompos kulit kopi : tanah ultisol) }\end{array}$ & Jumlah Anakan & $\begin{array}{c}\text { Jumlah Helai } \\
\text { Daun }\end{array}$ & $\begin{array}{c}\text { Bobot Kering } \\
\text { Akar }(\mathrm{g})\end{array}$ & $\begin{array}{c}\text { Nisbah Tajuk } \\
\text { Akar }\end{array}$ \\
\hline $30 \mathrm{~g}: 2.970 \mathrm{~g}(\mathrm{k} 3)$ & $13,73 \mathrm{a}$ & $43,27 \mathrm{a}$ & $3,35 \mathrm{a}$ & $1,25 \mathrm{a}$ \\
$15 \mathrm{~g}: 2.985 \mathrm{~g}(\mathrm{k} 1)$ & $13,00 \mathrm{a}$ & $42,93 \mathrm{a}$ & $2,97 \mathrm{a}$ & $1,19 \mathrm{a}$ \\
$22,5 \mathrm{~g}: 2.977,5 \mathrm{~g}(\mathrm{k} 2)$ & $12,93 \mathrm{a}$ & $42,87 \mathrm{a}$ & $2,66 \mathrm{a}$ & $0,99 \mathrm{a}$ \\
Kontrol $(\mathrm{k} 0)$ & $12,13 \mathrm{a}$ & $42,20 \mathrm{a}$ & $2,58 \mathrm{a}$ & $0,95 \mathrm{a}$ \\
\hline
\end{tabular}

Keterangan : Angka-angka yang diikuti oleh huruf yang sama berbeda tidak nyata pada uji Duncun taraf $\alpha$ 5\%

Tabel 1 menunjukkan bahwa pemberian kompos kulit kopi pada semua perlakuan menunjukkan hasil berbeda tidak nyata. Hal ini diduga karena faktor genetik tanaman sehingga dapat mempengaruhi pertumbuhan tanaman serai 
wangi, pada bobot basah akar dan bobot kering tajuk mengalami peningkatan pertumbuhan tanaman serai wangi dan pemberian kompos limbah kulit kopi pada berbagai dosis memberikan pengaruh yang nyata. Hal ini sejalan dengan pendapat Lakitan (2011) menyatakan bahwa pertumbuhan sistem perakaran akan menyimpang dari kondisi idealnya, jika kondisi tanah sebagai tempat tumbuhnya tidak optimal, namun apabila terjadi kebalikannya dapat dipastikan sistem perakaran tanaman sepenuhnya dipengaruhi oleh faktor genetis. Dugaan lainnya, penyebab berpengaruh tidak nyata dikarenakan pemberian pupuk starter yang sesuai dengan dosis anjuran.

Dari hasil analisis kompos limbah kulit kopi diperoleh nilai $\mathrm{C} / \mathrm{N}$ masih tinggi, mengakibatkan terjadinya persaingan antara mikroorganisme dengan tanaman dalam memperoleh unsur hara. Menurut Rosmarkam dan Yuwono (2002), bahwa bahan organik yang nilai $\mathrm{C} / \mathrm{N}$ yang masih tinggi akan membuat tanaman bersaing dengan mikroba untuk memanfaatkan unsur hara yang dikandung bahan organik. Penyebab tingginya rasio C/N kompos kulit kopi yang digunakan dalam penelitian ini adalah karena bahan baku kulit kopi yang dikomposkan sudah mengering. Selain itu, kulit tanduk buah kopi yang sudah mengering juga digunakan sebagai bahan kompos, dimana kulit tanduk ini mengandung senyawa lignin. Akibatnya pengomposan selama dua bulan belum terdekomposisi secara sempurna.

\section{Bobot basah akar dan bobot kering tajuk (g)}

Berdasarkan hasil analisis ragam menunjukkan bahwa pemberian kompos kulit kopi berpengaruh nyata terhadap bobot basah akar dan bobot kering tajuk tanaman serai wangi pada akhir penelitian (12 MST). Hasil Uji DNMRT taraf 5\% terhadap bobot basah akar dan bobot kering tajuk untuk setiap perlakuan dapat dilihat pada Tabel2.

Tabel 2. Rata-rata bobot basah akar dan bobot kering tajuk tanaman serai wangi pada berbagai dosis pemberian kompos kulit kopi pada umur 12 MST

\begin{tabular}{lcc}
\hline \multicolumn{1}{c}{ Perlakuan } & Bobot Basah Akar $(\mathrm{g})$ & Bobot Kering Tajuk $(\mathrm{g})$ \\
\hline $15 \mathrm{~g}: 2.985 \mathrm{~g}(\mathrm{k} 1)$ & $38,89 \mathrm{~b}$ & $11,12 \mathrm{~b}$ \\
Kontrol $(\mathrm{k} 0)$ & $31,34 \mathrm{ab}$ & $10,15 \mathrm{~b}$ \\
$30 \mathrm{~g}: 2.970 \mathrm{~g}(\mathrm{k} 3)$ & $19,00 \mathrm{a}$ & $8,43 \mathrm{ab}$ \\
$22,5 \mathrm{~g}: 2.977,5 \mathrm{~g}(\mathrm{k} 2)$ & $16,70 \mathrm{a}$ & $6,14 \mathrm{a}$ \\
\hline
\end{tabular}

Keterangan : Angka-angka yang diikuti oleh huruf yang sama berbeda tidak nyata pada uji Duncun taraf $\alpha 5 \%$

Tabel 2 menunjukkan bahwa pemberian kompos kulit kopi pada perlakuan k1 berbeda nyata terhadap perlakuan $\mathrm{k} 3$ dan $\mathrm{k} 2$, namun berbeda tidak nyata terhadap perlakuan $\mathrm{k} 0$. Bobot basah akar tertinggi terdapat pada perlakuan k1 38,89 dan bobot basah akar terendah terdapat pada perlakuan k2 16,70. Peningkatan bobot basah akar pada tanaman serai wangi sebesar $70,80 \%$ bila dibandingkan $\mathrm{k} 0$.

Dari Tabel 2 juga terlihat bahwa pemberian kompos kulit kopi perlakuan k0, k1 dan k3 berbeda tidak nyata, namun berbeda nyata terhadap perlakuan k2. Bobot kering tajuk tertinggi terdapat pada perlakuan k1 11,12 dan bobot kering tajuk terendah pada perlakuan k2 6,14. Peningkatan bobot kering tajuk pada tanaman serai wangi sebesar 49,06\% bila dibandingkan dengan k0.

Pemberian bahan organik pada media tanam dapat memperbaiki sifat fisik media tanam dari padat menjadi remah dan warna tanah menjadi gelap akibat adanya mikroorganisme di dalam tanah. Perbaikan sifat fisik, kimia dan biologi tanah akan menciptakan ruang tumbuh akar yang optimal. Optimalisasi ruang tumbuh akan meningkatkan daya jelajah dan kekauatan akar untuk menyerap unsur hara. Sejalan dengan pendapat Saljuna (2012) dalam Tumangger, Hapsoh dan Sukemi (2017), penambahan bahan organik ke tanah secara langsung dapat memperbaiki sifat kimia, fisika, biologi tanah serta meningkatkan pertumbuhan akar. Meningkatnya pertumbuhan akar akan mendorong terjadinya peningkatan suplai air dan unsur hara yang dibutuhkan untuk proses fotosintesis, sehingga fotosintat yang dibutuhkan untuk pertumbuhan akar, batang dan daun menjadi tersedia.

Pupuk organik dari kompos kulit kopi dapat menyediakan unsur hara pada tanaman. Berdasarkan hasil analisis kandungan unsur hara kompos kulit kopi yang digunakan yaitu C-Organik 46,68, Nitrogen 0,88\%, Fosfor 0,60\% dan Kalium $0,77 \%$. Kandungan unsur hara nitrogen, fosfor dan kalium pada kompos kulit kopi berfungsi untuk memperbaiki pertumbuhan vegetatif dan pembentukan protein, fosfor berfungsi untuk pembelahan sel, pertumbuhan akar dan memperkuat batang agar tidak roboh, kalium berfungsi untuk pembentukan pati dan memperkuat daya tahan terhadap penyakit (Hardjowigeno, 2007 dalam Sadewo, 2018).

Dengan pemberian pupuk organik ditambah dengan pemberian pupuk starter pada awal tanam dapat menyediakan unsur hara sehingga mendukung pertumbuhan tanaman serai wangi. Hal ini sejalan dengan pendapat Praniwirata et al, (1995) dalam Tumangger, Hapsoh dan Sukemi (2017) bahwa tanaman akan tumbuh subur jika unsur hara pada tanaman terpenuhi dalam jumlah yang cukup, sehingga unsur hara yang tersedia dapat digunakan 
Rosliana Manurung, Yulistiati Nengsih, dan Ridawati Marpaung. Pertumbuhan Tanaman Serai Wangi (Cymbopogon nardus L) Pada Beberapa Dosis Kompos Kulit Kopi

untuk proses fotosintesis. Hal ini ditunjukkan dengan meningkatkan bobot basah akar dan bobot kering tajuk pada tanaman serai wangi.

\section{Pengukuran pH tanah}

Hasil pengamatan terhadap $\mathrm{pH}$ tanah menunjukkan bahwa pemberian kompos kulit kopi berpengaruh nyata terhadap $\mathrm{pH}$ media tanam. Uji lanjut DNMRT taraf 5\% terhadap $\mathrm{pH}$ media tanam untuk setiap perlakuan dapat dilihat pada Tabel 7.

Tabel 3. pH media tanam pada berbagai dosis pemberian kompos kulit kopi

\begin{tabular}{lc}
\hline \multicolumn{1}{c}{ Perlakuan } & Nilai pH Media Tanam \\
\hline $15 \mathrm{~g}: 2.985 \mathrm{~g}(\mathrm{k} 1)$ & $6,33 \mathrm{~b}$ \\
$30 \mathrm{~g}: 2.970 \mathrm{~g}(\mathrm{k} 3)$ & $6,33 \mathrm{~b}$ \\
$22,5 \mathrm{~g}: 2.977,5 \mathrm{~g}(\mathrm{k} 2)$ & $6,17 \mathrm{~b}$ \\
Kontrol $(\mathrm{k} 0)$ & $5,00 \mathrm{a}$ \\
\hline
\end{tabular}

Keterangan : Angka-angka yang diikuti oleh huruf yang sama berbeda tidak nyata pada uji Duncun taraf $\alpha 5 \%$

Pada Tabel 7 menunjukkan bahwa pemberian kompos kulit kopi berbeda tidak nyata pada perlakuan k1, k2, dan $\mathrm{k} 3$, namun berbeda nyata terhadap perlakuan $\mathrm{k} 0$. $\mathrm{pH}$ media tanam yang terendah terdapat pada perlakuan $\mathrm{k} 0$ sebesar 5,00 dan pada perlakuan $\mathrm{k} 1$ dan perlakuan $\mathrm{k} 3$ memiliki $\mathrm{pH}$ 6,33 merupakan nilai $\mathrm{pH}$ media tanam tertinggi. Peningkatan $\mathrm{pH}$ dari kontrol sebesar 26,6\%.

Kompos kulit kopi merupakan bahan organik yang yang secara umum dapat memperbaiki sifat fisik dan kimia tanah kea rah yang sesuai untuk pertumbuhan tanaman. Hal ini sejalan dengan penelitian yang telah dilakukan bahwa pemberian kompos limbah kulit kopi memberikan pengaruh pada $\mathrm{pH}$ media tanam. Pemberian bahan organik mempengaruhi sifat kimia tanah dan dapat meningkatkan $\mathrm{pH}$ tanah. $\mathrm{pH}$ tanah sebelum diberi pupuk organik yaitu 5,0 dan setelah diberi pupuk organik $\mathrm{pH}$ media tanam menjadi 6,33.

\section{Hasil Analisis Unsur Hara dan pH Kompos Kulit Kopi}

Hasil analisis unsur hara dan $\mathrm{pH}$ kompos kulit kopi sebelum penelitian dilakukan di Laboratorium Balai Pengkajian Teknologi Pertanian Jambi didapatkan hasil sebagai berikut :

Tabel 8. Hasil analisis kimia pupuk kompos kulit kopi

\begin{tabular}{lcccccc}
\hline No & Kode Sampel & pH H20 & C-Organik & N Total & P Total & K Total \\
\hline 1 & POP (Pupuk Kompos Kulit Kopi) & 7,55 & 46,68 & 0,88 & 0,66 & 0,77 \\
\hline
\end{tabular}

\section{Suhu Dan Kelembaban Udara}

Pengukuran data tambahan meliputi suhu dan kelembaban. Pengukuran suhu dan kelembaban dilakukan pada pukul 06.00, 12.00 dan 18.00. Rata-rata suhu dan kelembaban dapat dilihat pada Tabel 8.

Tabel 4. Rata-rata suhu dan kelembaban di lokasi penelitian

\begin{tabular}{ccc}
\hline Waktu (WIB) & Suhu rata-rata $\left({ }^{\circ} \mathrm{C}\right)$ & Kelembaban rata-rata $(\%)$ \\
\hline 06.00 & 27,35 & 78,93 \\
12.00 & 29,59 & 70,19 \\
18.00 & 29,19 & 73,14 \\
\hline
\end{tabular}

Dari Tabel 8 menunjukkan bahwa suhu rata-rata di lokasi penelitian yang terendah yaitu 27,35 pada jam 06.00 WIB dan suhu tertinggi yaitu 29,59 pada jam 12.00 WIB. Rata-rata kelembaban udara terendah terdapat pada jam 18.00 WIB yaitu $73,14 \%$, sedangkan rata-rata kelembaban udara tertinggi terdapat pada jam 06.00 WIB yaitu 78,93 $\%$.

Dari hasil pengamatan pengukuran suhu dan kelembapan menunjukkan bahwa rata-rata suhu di lokasi penelitian adalah $27,35^{\circ} \mathrm{C}$ pada pukul $06.00,29,59^{\circ} \mathrm{C}$ pada pukul 12.00 dan $29,19^{\circ} \mathrm{C}$ pada pukul 18.00 (WIB) dan rata-rata kelembapan adalah 78,93\% pada pukul $06.00,70,19 \%$ pada pukul $12.00,73,14 \%$ pada pukul 18.00 (WIB). Menurut BPTP Aceh (2016) tanaman serai wangi dapat tumbuh dengan baik pada kisaran suhu antara $10-33^{\circ} \mathrm{C}$ dengan sinar matahari yang cukup dan kelembapan diatas 75\% (Feriadi, 2018 dalam Sadewo, 2018). Dengan 
Rosliana Manurung, Yulistiati Nengsih, dan Ridawati Marpaung. Pertumbuhan Tanaman Serai Wangi (Cymbopogon nardus L) Pada Beberapa Dosis Kompos Kulit Kopi

demikian suhu dan kelembapan di lokasi penelitian masih dalam rentang yang optimal serta telah memenuhi persyaratan tumbuh serai wangi.

\section{Serangan Hama Dan Penyakit}

Dari hasil pengamatan terdapat 3 (tiga) tanaman serai wangi yang terserang hama dan penyakit. Hama yang ditemuai yaitu kutu putih Hama ini mudah dideteksi karena biasanya tampak bergerombol pada bagian bawah daun dan pangkal batang. hama ini menyerang tanaman inang dengan menusuk dan menghisap cairan tumbuhan sehingga tanaman menjadi kering. serangan penyakit yaitu layu fusarium dengan gejala menguningnya daun bagian bawah yang kemudian menjadi layu dan pada batang tanaman membusuk dan berwarna coklat.

\section{KESIMPULAN}

Dari hasil penelitian dan analisis data yang telah dilakukan maka dapat diambil kesimpulan bahwa pemberian kompos kulit kopi berpengaruh nyata terhadap parameter bobot basah akar, bobot kering tajuk, dan $\mathrm{pH}$ media tanam tetapi berpengaruh tidak nyata terhadap parameter jumlah anakan, jumlah helai daun, bobot kering akar dan nisbah tajuk akar. Terjadi peningkatan pada bobot basah akar sebesar 70,80\% dan peningkatan bobot kering tajuk sebesar 49,06\% dibanding tanpa pemberian kompos limbah kulit kopi .

\section{DAFTAR PUSTKA}

Ditjenbun. 2006. Pedoman Pemanfaatan Limbah Dari Pembukaan Lahan. Direktorat Jenderal Perkebunan. Departemen Pertanian.

Efendi, D., Sufardi dan Muyassir. 2014. Aplikasi Biochar Dan Kompos Kulit Kopi Untuk Meningkatkan Hasil Kentang Pada Andisol Atu Lintang Kabupaten Aceh Tengah. Jurnal Manajemen Sumberdaya Lahan.3 (2) : 452-458.

Hutapea, R., Armaini, dan Isnaini. 2018. Pemberian Beberapa Dosis Kompos Kulit Kopi Terhadap Pertumbuhan Bibit Karet (Hevea brasilliensis Muell Arg.) Stum Mini. JOM Faperta. 5 (1) : 1-13.

Lakitan. 2011. Dasar-Dasar Fioslogi Tumbuhan. PT. Raja Grafindo Persada. Jakarta

Marsono dan Paulus. 2011. Pupuk Akar Jenis Aplikasi. Penebar Swadaya. Jakarta.

Melisa. 2018. Studi Pemanfaatan Limbah Kulit Kopi Toraja Sebagai Bahan Pembuatan Kompos. Universitas Hasanuddin.

Murbandono, L. 2008. Membuat Kompos Edisi Revisi. Penebar Swadaya. Jakarta.

Ramli, D. Zulfita \& M. Safwan. (2013). Pengaruh Kompos Kulit Buah Kopi Terhadap Pertumbuhan dan Hasil Tanaman Petsai pada Tanah Aluvial. Jurnal Fakultas Pertanian Universitas Tanjungpura Pontianak.

Rosmarkam, A., dan N.W. Yuwono. 2002. Ilmu Kesuburan Tanah. Kanisius. Yogyakarta. Hal 153-157.

Rusli, S., N. Nurdjanah, Soediarto, D. Sitepu, Ardi, S dan D.T. Sitorus. 1990. Penelitian dan pengembangan minyak atsiri Indonesia,Edisi Khusus Penelitian Tanaman Rempah dan Obat. Balai Penelitian Tanaman Rempah dan Obat. Bogor. Hal 10-14.

Sadewo, P. 2018. Agroforestri Serai Wangi (Cymbopogon nardus L.) Generasi M1 Hasil Iradiasi Sinar Gamma Dengan Jati (Tectona grandis Linn.). Skripsi. Institut Pertanian Bogor. Bogor. Hal 11-25.

Setiawan, Gusmaini dan H. Nurhayati. 2018. Respons Tanaman Serai Wangi Terhadap Pemupukan NPKMg Pada Tanah Latosol. Buletin Penelitian Tanaman Rempah dan Obat. 29 : 69-78.

Sopacua, B. N. 2016. Pengaruh Pemupukan Dan Jarak Tanam Terhadap Pertumbuhan Tanaman Serai Wangi (Cymbopogon citratus). Jurnal Triton. $7:$ 51-60.

Tumangger, R.F., Hapsoh dan Sukemi. 2017. Pengaruh Pemberian Kompos Kulit Kopi Dan Pupuk NPK Terhadap Pertumbuhan Bibit Kelapa Sawit (Elaeis guineensis Jacq.) Di Pembibitan Utama. JOM Faperta UR. 4 (1).

Valentiah, F. V., E. Listyarini dan S. Prijono. 2015. Aplikasi Kompos Kulit Kopi Untuk Perbaikan Sifat Kimia Dan Fisika Tanah Inceptisol Serta Meningkatkan Produksi Brokoli. Jurnal Tanah dan Sumberdaya Lahan. 2 (1) : 147-154. 